\title{
SOBRE A VIDA E OUTRAS COISAS
}

Francisco Neto Pereira Pinto ${ }^{1}$

"a vida vale ou não vale a pena ser vivida"

Albert Camus

Quando Pedro me enviou a mensagem apesar das poucas palavras sabia que era algo a não se desprezar preciso falar com você disse assim seco e direto em seu tom de urgência Nos encontramos lá na marginal neblina no virar do dia $\mathrm{O}$ sol já se escondia mas a noite ainda não havia chegado havia bem discretos raios meios pálidos que se escorregavam por entre as folhas das palmeiras e davam leves tapas nas bochechas rosadas de Pedro como que o encorajando a falar Pedro fala à prestação sempre muito econômico e preciso $\mathrm{Na}$ verdade não fala palavras derrama mesmo é a vida Olhou em meus olhos e depois fitou a água lá no córrego que corria já fria com a entrada da noite Uma gota de suor escorreu Recebi hoje uma noticia nada boa disse com sua voz grave em tom baixo a Ana está grávida Avancei para abraça-lo pois afinal tinham feito todos os preparativos para expandirem a família a notícia então era um forte indicativo de que os planos estavam sendo selados com êxito mas como um lampejo me segurou a expressão nada boa João nascemos quase juntos por pouco teríamos a mesma mãe sussurrou Pedro palavras molhadas de lágrimas lágrimas que se derramavam na voz entrecortada que agora mirava não mais meu rosto, mas o chão da pista, pelo qual escorregava um fina poeira sendo levada pelo vento de despedida do outono e de celebração do inverno A Ana não sabe e nem eu sabia mas fiz exames e não posso ser pai Como João ela pode estar grávida Para estas últimas palavras ele mal abriu a boca cerrou dentes e punhos e seu corpo estremeceu Abracei o Pedro que estava com respiração ofegante e em seu peito podia sentir um cavalo a mais que em galope $O$ silêncio caiu do alto não somente entre nós dois mas em toda a rua e nas casas ao redor Apenas um chiado constante e calmo da água do córrego que continuava seu trajeto alheia e indiferente a dor daquele que desde que conheceu Ana lhe foi inteiramente dedicado Depois de um tempo paralisado se deixou abraçar Com seu abraço veio não somente o peso de um corpo

\footnotetext{
1 Aluno de Doutorado no Programa de Pós-Graduação em Ensino de Língua e Literatura e Mestre pelo mesmo Programa. Especialista em Leitura e Produção Escrita e Graduado em Letras - Inglês/Português. Atualmente é professor convidado na Universidade Federal do Tocantins, campus de Araguaína.
} 
robusto e sofrido mas também quilos de decepção vertendo em lágrimas Jamais o havia visto se derramar tão sem amarras como a água que se precipita de uma cachoeira sem se preocupar com o antes ou o depois mas apenas com o derramar-se inteiramente fiel ao seu propósito correr irrigar arejar restituir e fortalecer a vida Pedro não era um homem extraordinário mas era comprometido e dedicado Quando foram se casar o fizeram à revelia da mãe dela pois era arrimo de família A sogra nem mesmo compareceu à cerimônia como sinal de protesto e desde sempre não dispensa alfinetá-lo culpando-lhe ora pela solidão ora pelas dores que sente em ter de ser a única responsável por todas as tarefas domésticas Se não é feliz claro a culpa é de Pedro que lhe tirou de casa a Ana Contudo ele prefere fingir que não entende ou às vezes faz esforço extra em não ceder à tentação sabendo que uma pedrada na mãe o que se acerta é sempre a filha Ana sempre foi seu marco zero

\author{
O meu amor é a minha poesia \\ mais bela e de cada dia \\ Amo você prosaico e em verso \\ direito e avesso \\ e autorreverse
}

Agora e para sempre

Amém

Ana é como a noite os mistérios e a certeza nela fazem moradia Emprega sua palavra como fiança ao que quer que queira pois como último recurso entregaria a vida para mantê-la Sua honra está na palavra se diz tem de acontecer Ana é uma onda do mar um estrondo o canto da sereia Pedro está sempre consigo Loira e bela estudou fez direito e é chamada de doutora Em seu escritório um grande pôster seu na parede e uma pequena foto do casal na mesa Mais felizes não poderiam ser e o que mais Ana quisesse Pedro lhe daria exceto filhos e disso ele ainda não sabia Outro dia Ana quis que mudassem de casa e bairro o que Pedro logo providenciou Depois foi o que carro e ele logo trocou Ana sempre diz que Pedro não somente é responsável por ela mas também por todos os seus gastos e que seu dinheiro serve apenas para necessidades pessoais portanto somente seu para não ter de prestar informações com o que e como gasta pois isto lhe seria demais Por último esta Ana quis 
filho um filho então ela terá No olhar de Pedro descansam os sonhos A serenidade recobrada parece ter vindo com a brisa patrocinada pela noite já triunfante Nenhuma palavra a mais para falar Pedro já quase um vulto se despediu com um abraço agradecido e saiu caminhando calmamente

O Pedro é uma lagoa

Às vezes um passarinho

Uma madrugada chegando devagarinho 